\title{
Determination of Adulteration and Chemical Composition of Raw Milk Sold in Hossana Town, South Ethiopia
}

\author{
Haftu Kebede Sebho* and Degnet H Meskel \\ Department of Animal Sciences, Wachemo University, Ethiopia
}

Submission: June 12, 2018; Published: July 23, 2018

*Corresponding author: Haftu Kebede Sebho, Department of Animal Sciences (Animal Production), College of Agricultural Sciences, Wachemo University, P.O. Box 667, Hossana, Ethiopia, Tel: +251937647687; Email: Haftuk2001@gmail.com

\begin{abstract}
The present study was designed to analyze chemical composition, organoloptic evaluation and adulteration condition of milk sold in Hossana town, Ethiopia during the year 2015/16. A total of thirty (30) milk samples were collected, each of ten ( $n=10)$ from milk producers (MP), cafeteria and control. Results showed that maximum fat, protein, lactose density, solid-not-fat, total solid and water contents were observed in samples S3 (4.65\%), S1 (3.40\%), S2 (4.24\%), S2 (31.94\%), S2 (5.65\%) S1(9.3\%) and S1 (11.17\%) respectively. The results for raw milk sample for evaluating the chemical composition (protein, density, solid-not-fat, and total solid) showed that there is no significant difference ( $p>0.05$ ) statistically. The statistical analysis showed that the fat and water contents of these milk samples collected from different sources were significantly different $(\mathrm{p}<0.01)$. Clot-on-boiling test (COB) and alcohol test (AT) showed that milk sample from house hold milk has superior quality as compare to cafeteria milk. $90 \%$ and $80 \%$ milk samples from milk producer and cafeteria respectively were successfully pass on clot-on-boiling test, whereas (80\% and $70 \%$ milk samples from milk producer and cafeteria respectively were successfully pass on alcohol test. In organoleptic test, the result was based on physical appearance (sensory evaluation) system. Ninety percent (90\%) milk samples from milk producer were normal (white in color) and $10 \%$ were abnormal (yellowish white). Whereas (80\%) milk samples from cafeteria were normal and 20\% were abnormal (yellowish white). $70 \%$ and $67 \%$ milk samples from milk producer and cafeteria respectively were normal in odor/Smell. In general, it is not fair to conclude that some of the milk quality parameter sold at Hossana city, met the minimum legal standards of normal milk. Therefore, it is recommended that introducing different dairy technologies should be supported with a continuous training on how to manage a dairy farm. Stronger milk quality control and quality base payment could help a lot to discourage adulteration.
\end{abstract}

Keywords: Cafeteria; Fat; Lactose; Protein; Solid Non-Fat; Total Solid; Protein; Density; Vitamins; Minerals; Adulteration; Milk; Goats; Camels; Nutritious food; Pathogens; Livestock; Alcohol; Boiling

Abbreviations: AT: Alcohol Test; COB: Clot-On-Boiling test; MP: Milk Producers; ES: Ethiopian Standard; EU: European Union; APT: Alcohol Perception Test; SNF: Solids Not Fat Percentage; FDA: Food and Drug Administration

\section{Introduction}

The cattle population in Ethiopia is estimated to be about 53.9 million, out of which female cattle constitute about 55.4 percent. About $98.95 \%$ of the total cattle are local breeds and the remaining are hybrid and exotic breeds [1]. Dairy production is a critical issue in Ethiopia-a livestock-based society-where livestock and its products are important sources of food and income, and dairying has not been fully exploited and promoted. The annual milk production is estimated about 3.8 billion liters from cattle and 165 million liters from camel [2]. Ethiopia has a huge potential for dairy development, with the number of milking cows estimated to be around 9.9 million heads [3]. Cattle milk constitutes the larger proportion of the milk produced nationally (83\%), with the remainder coming from goats and camels [4].
Milk is a compensatory part of daily diet especially for the expectant mothers as well as growing children [5,6]. Milk is a perfect food, readily digested and absorbed for maintenance of health in adults. It is chiefly a valuable source of good quality protein, fat, carbohydrates, vitamins and minerals [7]. According to [8], the major components of milk are water (87.4\%), milk solids $(12.60 \%)$, solids-not-fat $(9.0 \%)$, fat $(3.60 \%)$, protein $(3.40 \%)$, milk sugar or lactose $(4.90 \%)$ and ash or minerals $(0.70 \%)$. The constituents may vary with genetic (breed and individual cow and variability among cows within a breed) and environment (interval between milking, stage of lactation, age, feeding regime, disease and completeness of milking). It is a well-established fact that consumers want clean, wholesome 
and nutritious food that is produced and processed in a sound, sanitary manner and is free from pathogens. Hence, for fulfilling consumer's demand, quality milk production is necessary. Quality milk means, the milk which is free from pathogenic bacteria and harmful toxic substances, free from sediment and irrelevant substances, of good flavor, with normal composition, adequate in keeping quality and low in bacterial counts [9].

In Ethiopia, milk is produced in urban and rural areas mostly in non-organized way and usually supplied to the consumers in raw form. Because of its high demand and seasonality in supply, dishonest producers and traders deliberately adulterate milk and its products to promote the level of these essential nutrients after reduction of a given amount, increase their profit margin by several chemicals like urea and increase its volume by adding substances such as starch, flour, cane sugar, vegetable oils, preservatives, water, skim milk, etc. [10]. This ultimately leads to the stage that the consumer is either cheated or often becomes victim of diseases [7]. Such types of adulteration are quite common in developing countries. However, there is scarcity of information regarding the milk composition and physical evaluation in Hadiya Zone in general and Hossana city in particular. Understanding the factors affecting the milk quality is critical to success of improvement and implementation of policies in dairy industry. Keeping in view the above facts, the present study was conducted to achieve the following: -

\section{Objective}

i. To determine the chemical composition of the milk available in the study area.

ii. To detect water adulteration in milk in the study area.

iii. To determine the physical evaluation of milk in the study area.

\section{Materials and Methods}

\section{Description of the Study Area}

The study was conducted in Hossana city of Hadya zone, Southern Nations, Nationalities and People Regional State (SNNPRS). Hosanna town is located $232 \mathrm{Km}$ away from Addis Ababa, in the south direction. The area is situated at midland with an altitude of 1800 masl and exhibit a bimodal rainfall system (long and short rainy season). The long rainy season extends from June to September, whereas the short rainy season ranges from mid-February to the end of April. The living style of the people depends on agriculture, predominant, using mixed crop - livestock farming system. The maximum annual temperature does not exceed $26^{\circ} \mathrm{C}$ and mean minimum temperature varies from 11.2 to $19.2{ }^{\circ} \mathrm{C}$.

\section{Sampling Techniques}

Purposive and randomly sampling procedures were used to select farm households. The study kebeles (Bobicho, Jole narramo, Lichamba and Melamba) were selected intentionally based on number of crossbred cows distributed and milk production potential. Lists (census) of households of the selected areas were obtained from Hossana Agriculture and Rural Development Offices. Finally, a total of 30 households were selected randomly.

\section{Methods of Milk Sampling}

A total of thirty milk samples were taken (10 from farmers, 10 from milkier and 10 cafeterias). Samples of raw morning milk were taken from each household once every week over a period of four weeks for determination of chemical composition and physical examination of raw milk following standard methods as described by [11]. The cows, which were selected for milk sample collection, were physically evaluated for health and hygienic condition prior to sampling. $250 \mathrm{ml}$ milk samples were collected aseptically from individual cows milking from containers immediately after milking. Crossbred cow's milk was collected in different week in different bottle for milk chemical composition analysis. Fresh cow milk, in cans and bulk tanks, were thoroughly mixed to disperse the milk fat before collection of milk sample for physico chemical analysis. The samples collected were placed in a sterile container and kept in an ice box while transporting to Addis ababa shoal milk enterprise dairy laboratory for chemical analysis with a minimum of delay. Each farmer or cafeterias were visited twice for sample collection. In the First week, 10 samples from each farmer, from milkier and cafeterias were collected and analyzed. In the second week, following the same procedure 10 samples from each were collected for laboratory analysis. Every sample was divided in to three parts: one for physical examination, second for chemical composition and third for water adulteration. All samples were done in duplicates. The following analysis was carried out.

\section{Physical Examination}

The ten panelists were selected from Animal Science Department to assess the sensory acceptability of milk that collect from the study site. Each sample was observed for general appearance (presence of dirt), odor (mild and cowey), color (yellow and bloody), consistency (thin or watery) and sediments with the help of a panel of expert according to [12].

\section{Clot on Boiling Test}

This test was performed according to the method described by [13] for acid milk having pH less than 5.8 or abnormal milk (e.g. colostral or mastitis milk) to assess milk acidity. The alcohol test was done by using a $68 \%$ ethanol solution. Tests were done immediately after the samples were delivered to the laboratory. $2 \mathrm{ml}$ of the raw milk sample was taken and mixed with 68 percent ethanol solution in a sterile test tube. The solution was prepared from $68 \mathrm{ml} 96$ percent alcohol and with $28 \mathrm{ml}$ of distilled water.

\section{Alcohol Perception Test}

This test was also performed according to method of [13]; the test is based on the proteins (instability) and concentration of acid or rennet is increased. Test assesses the increased levels of albumen colostrum milk and salt concentrates (mastitis). 


\section{Chemical Analysis}

Analyses were performed at addiss ababa (shoal Milk enterprise dairy laboratory) according to Lacto scanner (Dr Gerber, Germany), [14] methods to determine the composition (density, lactose, protein, total fat, total solid and water adulteration). Percent Solids-not-fat was calculated by the following equations: $\% \mathrm{SNF}=\%$ Total solids $-\%$ fat.

\section{Statistical Analysis}

The raw milk samples were analyzed for physical appearance, quality and presence of adulterants. The data obtained was tabulated and analyzed according to statistical procedure of analysis of variance (ANOVA) and significant differences of the mean was further computed using Duncan's Multiple Range Test at $0.05 \%$ level of probability through computerized statistical package. Pearson correlation and multiple regressions were used to analyze the association between milk quality parameters.

\section{Results and Discussion}

All the results from the analysis of milk compared to the standard values suggested by Ethiopian standard (ES) and European Union (EU) quality standards were presented in the Table 1.

Table 1: Comparison between nutrient contents of samples and Ethiopian standard (ES).

\begin{tabular}{|c|c|c|c|}
\hline $\begin{array}{c}\text { Nutrients } \\
\text { (\%) }\end{array}$ & $\begin{array}{c}\text { Samples } \\
\text { (n=30) Mean } \\
\text { values for } \\
\text { (S1, S2 and } \\
\text { S3) }\end{array}$ & $\begin{array}{c}\text { Ethiopian } \\
\text { Standard (ES) \% }\end{array}$ & $\begin{array}{c}\text { European } \\
\text { Union (EU) } \\
\text { quality } \\
\text { standards } \\
\text { (Raff, 2011) \% }\end{array}$ \\
\hline Fat & 3.96 & 3.5 & 3.25 \\
\hline Lactose & 3.83 & NA & 4.2 \\
\hline Protein & 3.13 & 3.2 & 2.73 \\
\hline SNF & 4.82 & NA & 8.25 \\
\hline Total Solid & 8.78 & 12.8 & 12.5 \\
\hline
\end{tabular}

NA: Not Available.

\section{Fat Percentage of Examined Milk Samples}

Our results showed that maximum fat was observed in sample S3 (4.65\%) followed by S1 (4.02\%), while minimum was observed in sample S2 (3.21\%) followed by S4 (3.09\%) (Table 2). While among the milk samples the fat content of milk obtained from the control (S3) seems to be higher (4.65\%), compared to that of milk samples obtained from the sale points of S2 (4.02) and S2 (3.21) respectively. The results showed that there was significant $(\mathrm{P}<0.01)$ difference among samples in fat contents (Table 2). The maximum fat yield observed in the present study is lower than the average fat (5.22\%) for crossbred cows in selected areas of Amhara and Oromia National Regional States, Ethiopia reported by [15]. The overall mean fat content of $3.71 \%$ in the study areas was lower than what was reported by [16] for cooperative smallholders in Ethiopia (4\% fat). However, the peak fat yield in the present study (4.65\%) was higher than with what was reported by [17] (4.27\%) in west Shoa zone, Oromia Region, Ethiopia and [18] for HF crossbred dairy cows in Western Amhara Region, Ethiopia (4.17\% fat). This result is in accordance with the finding of [19], which stated that high fat percent crossbred cows $(5.02 \%)$. The maximum value of the fat $(4.65 \%)$ in the study area is higher than the minimum quality standard value of Ethiopian (ES) value (3.50\%), [20]. According to Food and Drug Administration (FDA) a minimum fat content of whole milk is $3.25 \%$ [21]. The value of protein content obtained in the current study fulfills the criteria developed by FDA and ES for the consumers. This difference in percent fat content may be due to the difference in feeding and management practices of the animals [22]. The low-fat content in S2 and S4 may be due to attributed to adulteration by addition of water or partial skimming.

\section{Protein Percentage of Milk Samples}

Results showed that maximum protein content was observed numerically in sample S1 (3.40\%) followed by S2 (3.24\%), while minimum was observed in sample S4 $(2.99 \%)$ followed by S3 $(2.75 \%)$ however, the differences among them were statistically not significant $(\mathrm{P}>0.05$ ) (Table 2$)$. The maximum protein content $(3.40 \%)$ in the present study is higher than with the findings of [15] and who reported that the average Protein was (3.12\%) in selected areas of Amhara and Oromia National Regional States, Ethiopia. However, the highest protein content in the present study $((3.40 \%))$ was in accordance with what was reported by [17] (3.67) in west Shoa zone, Oromia Region, Ethiopia and [18] (3.34\%) for HF crossbred dairy cows in Western Amhara Region, Ethiopia. The highest value of protein $(3.40 \%)$ in the present study area is slightly higher than the minimum quality standard value of Ethiopian (3.20\%), [20], but similar with the protein content observed in S2 (3.24\%). According to Food and Drug Administration (FDA) a minimum protein content of whole milk is $2.73 \%$ [21]. The value of protein content obtained in the current study fulfills the criteria developed by FDA for the consumers.

\section{Milk Total Solids Percentage of Examined Milk Samples}

Total solids are one of the parameter used for the quality of milk. Our results showed that maximum total solids were recorded in sample S1 (9.3\%) followed by sample S2 (8.87\%), while minimum was recorded in sample S3 (8.17\%) followed by S4 (7.38\%) (Table 2). Among the milk samples the total solids content of milk obtained from S3 (8.17\%) seems to be lower compared to that of milk samples obtained from the sale points of S1 (9.3\%) and S2 (8.87\%) respectively, however, the differences among them were statistically not significant $(\mathrm{P}>0.05)$ (Table 2$)$. The maximum total solids content in the present study (9.3\%) was lower than with what was reported by [18] for HF crossbred dairy cows in Western Amhara Region, Ethiopia (13.48 \%). Moreover, the maximum total solids (9.3\%) yield observed in the present study is lower than the mean of $13.07 \%$ for crossbred cows in west Shoa zone, Oromia Region reported by [17] and 
$13.15 \%$ for crossbred cows' milk in Bahir Dar milk shed area reported by [23]. In our sample, total solids (8.78) percentages were lower than the Ethiopian Standard (12.8). According to European Union recognized quality standards for total solids content of cow milk is not to be less than $12.5 \%$ [24]. In view of that, the total solid content obtained from the present study both household milk producers and cafeteria were below the quality standards.

\section{Solids Not Fat Percentage (SNF \%) of Examined Milk Samples}

Results presented in (Table 2) reveal that milk samples of cafeteria (S2) were better in SNF content (5.65\%), compared to that of milk samples from farmer (S1) 5.28\%. Moreover, the SNF content of milk sold at both areas was comparatively higher than that of control milk numerically $(3.52 \%)$. However, the differences among the samples were statistically non-significant ( $P>0.05)$. The maximum SNF\% (5.65\%) yield observed in the present study is lower than the $8.44 \%$ for crossbred cows in selected areas of Amhara and Oromia National Regional States, Ethiopia reported by [15], $9.31 \%$ reported by [18] in Western Amhara Region, 8.89 reported by [17] for Holstein Friesian crossbred cows in west Shoa zone, Oromia Region , 8.96 for Holstein Friesian crossbred cows reported by [23] in Bahir Dar milk shed area Ethiopia and $8.75 \%$ in Dire Dawa town reported by [25]. According to Food and Drug Administration (FDA) as well as European Union (EU) quality standards, a minimum solids-not fat (SNF) content of whole milk is $8.25 \%$ and $8.5 \%$ [26], respectively. In view of that, the result obtained in the present study area was within the quality standards given by FDA and EU.

\section{Density of Examined Milk Samples}

The average density content of milk producer (S1), cafeteria (S2), control (S3) and control + water (S4) was presented in Table 2. While among the milk samples the density content of milk obtained from the cafeteria (S2) seems to be higher (31.94\%), compared to that of milk samples obtained from the farmer (S1) (27.62\%), however, the differences among them were statistically not significant $(\mathrm{P}>0.05)$ (Table 2$)$. The maximum density content of S2 $(31.94 \%)$ in the study areas was slightly higher than what was reported by [15] for cross breeds cows in Ethiopia (28.70\%), but this was in accordance with (S1) (27.62\%) and (S3) (28.10).

Table 2: Chemical Composition of cow raw milk in the study area.

\begin{tabular}{|c|c|c|c|c|c|c|c|}
\hline Quality parameters & S1 & S2 & S3 & S4 & F Value & Pr $>$ F & SL \\
\hline Fat (\%) & $4.02(0.07)^{\mathrm{ab}}$ & $3.21(0.24)^{\mathrm{bc}}$ & $4.65(0.84)^{\mathrm{a}}$ & $3.09(0.01)^{\mathrm{c}}$ & 8.4 & 0.01 & $* *$ \\
\hline Solid -Non -Fat (\%) & $5.28(1.61)$ & $5.65(0.86)$ & $3.52(0.94)$ & $4.29(0.01)$ & 1.75 & 0.25 & NS \\
\hline Density (\%) & $27.62(3.39)$ & $31.94(3.83)$ & $28.10(1.03)$ & $25.76(0.65)$ & 1.96 & 0.22 & NS \\
\hline Total solid & $9.3(1.68)$ & $8.87(1.02)$ & $8.17(0.09)$ & $7.38(0.02)$ & 1.28 & 0.36 & NS \\
\hline Protein (\%) & $3.40(0.62)$ & $3.24(0.37)$ & $2.99(0.03)$ & $2.75(0.07)$ & 1.09 & 0.42 & NS \\
\hline Lactose & $3.91(0.51)^{\mathrm{ab}}$ & $4.24(0.16)^{\mathrm{a}}$ & $3.33(0.09)^{\mathrm{b}}$ & $3.19(0.01)^{\mathrm{b}}$ & 6.08 & 0.02 & $*$ \\
\hline Water adulteration (\%) & $1.08(1.88)^{\mathrm{b}}$ & $2.30(3.99)^{\mathrm{b}}$ & $0.00(0.00)^{\mathrm{b}}$ & $11.17(0.23)^{\mathrm{a}}$ & 8.37 & 0.01 & $* *$ \\
\hline
\end{tabular}

Numbers in bracket are standard deviation; Means with in a row with different superscripts are significantly different, ${ }^{*}$ : Significant at $(P<0.05)$,

**: Significant at $(P<0.01)$, NS: Non- significant $(P>0.05)$, SL: Significant level, S1: Milk from producer; S2: Milk from Cafeteria; S3: Control; S3: Control plus 5\%water; SL: Significant level.

\section{Lactose Percentage of Examined Milk Samples}

Table 2 shows that among the milk samples the lactose content of milk obtained from the cafeteria level seems to be higher $(4.24 \%)$ compared to that of milk samples obtained from the sale points of farmer (3.91\%) and control (3.33\%). The results showed that there was significant $(\mathrm{P}<0.05)$ difference among treatments in lactose content of milk. The highest lactose content in the present $(4.24 \%)$ was lower than with what was reported by [18] for HF crossbred dairy cows in Western Amhara Region, Ethiopia (5.26 \% Lactose). Lactose content may be affected by the presence of bacteria in raw milk as a result of storage temperature differences [27]. The lactose content of milk though can range from 3.6 to $5.5 \%$ [28]. So, the percentage of lactose found in the current study was $4.24 \%$, which is similar to that reported by [28].

\section{Water Adulteration of Examined Milk Sample}

Water is the most common adulterants in milk which is often added to increase the quantity of milk by scrupulous milk sellers to be paid simple money. Milk samples randomly collected from milk producers (S1) and cafeteria (S2) at Hossana city of Hadiya zone were examined for water adulteration. Results presented in Table 2 showed that maximum water content was recorded in sample S4 (11.17\%) followed by sample S2 (2.30\%), while minimum was recorded in sample S1 (1.08\%) followed by S3 $(0.0 \%)$. In the present study the extent of irrelevant water found to be comparatively higher $(\mathrm{P}<0.01)$ in milk sold at $\mathrm{S} 4(11.17 \%)$ than that of milk sold by S1 (1.08\%), S2 $(2.30 \%)$ and S3 $(0.00 \%)$ Table 2. The results in S1 (1.08\%) and S2 (2.30\%) approximately agreed with those previously achieved (1.19\%) by [15]. For the fulfillment of the gap between demand and supply different milk 
marketing dealers adulterated the milk by adding water which is probably carried out during the handling of milk starting from milking till it reaches the consumer or end user (Figure 1).

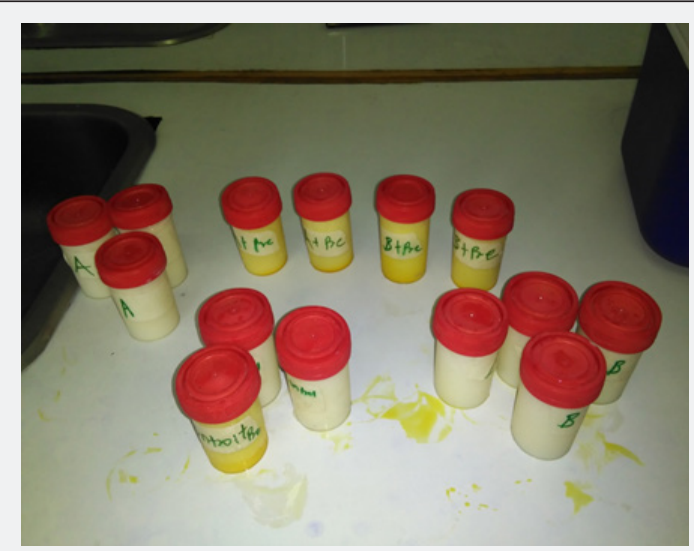

Figure 1: Sample of milks prepared for determination of physicochemical properties.

\section{Physical Examination}

The results regarding organoleptic characteristics test are presented in Table 3. Overall acceptability includes many implications, which is the important parameter in organoleptic estimation. The overall acceptance expresses how the consumers or panelists accept the product generally. Results of present study showed that $67 \%$ of the milk samples from farmers and cafeterias had clear general appearance; $70 \%$ and $67 \%$ showed normal odor/ smell. The smell for milk producer and control was almost equal to normal smell of milk but in case of cafeteria the smell was slightly bitter than normal taste of milk. This smell differences among the milk sources may be due to long term storage and lack of storage facilities. The results show that milk sample from producer and control has normal (yellowish white) color as compared to the cafeteria sources. However, the color of cafeteria sources is slightly different from producer and control milk source and shows more yellowish pale color than normal milk color. The color difference in milk was might be due to observed due to change in feeding habits of animal. $80 \%$ and $70 \%$ samples had normal consistency and $100 \%$ samples had no sediments in it, milk collected from various farmers and cafeterias, respectively. All this may be considered as hindrances to accept such milk for human consumption. The results for physical examination of milk clearly showed that the milk sold at farmers and cafeterias was slightly put to the mismanagements such as adulteration with water that probably carried out during the handling of milk starting from milking till it arrived at the end consumers. As a result the milk marketed at farmers and cafeterias cannot in all fairness. Overall evaluation of farmer milk samples and control was better than the cafeteria sources of milk (Table 3).

Table 3: Organoleptic evaluation of milk samples collected from farmer and cafeterias in the study area.

\begin{tabular}{|c|c|c|c|c|c|c|c|c|}
\hline \multirow{2}{*}{$\begin{array}{c}\text { Examinations } \\
\begin{array}{c}\text { General Appear- } \\
\text { ance }\end{array}\end{array}$} & \multicolumn{2}{|c|}{ Milk producers (MP) } & \multicolumn{2}{|c|}{ Cafeterias } & \multicolumn{2}{|c|}{ Control } & \multicolumn{2}{|c|}{ Control + $5 \%$ water } \\
\hline & $67 \%$ Clear & $33 \%$ unclean & $67 \%$ clear & $33 \%$ unclean & $90 \%$ Clear & $10 \%$ unclean & $88 \%$ clear & $12 \%$ unclean \\
\hline Odor/Smell & $70 \%$ normal & $\begin{array}{l}30 \% \text { abnor- } \\
\text { mal }\end{array}$ & $67 \%$ normal & $\begin{array}{c}33 \% \text { abnor- } \\
\text { mal }\end{array}$ & $100 \%$ normal & $0 \%$ abnormal & $100 \%$ normal & $0 \%$ abnormal \\
\hline Colour & $90 \%$ normal & $\begin{array}{c}10 \% \\
\text { abnormal }\end{array}$ & $80 \%$ normal & $\begin{array}{l}20 \% \text { abnor- } \\
\text { mal }\end{array}$ & $100 \%$ normal & $0 \%$ abnormal & $100 \%$ normal & $0 \%$ abnormal \\
\hline Consistency & $80 \%$ normal & $\begin{array}{l}20 \% \text { abnor- } \\
\text { mal }\end{array}$ & $70 \%$ normal & $\begin{array}{c}30 \% \text { abnor- } \\
\text { mal }\end{array}$ & $85 \%$ normal & $\begin{array}{c}15 \% \text { abnor- } \\
\text { mal }\end{array}$ & $65 \%$ normal & $\begin{array}{c}\text { 35\% abnor- } \\
\text { mal }\end{array}$ \\
\hline Sediment & $\begin{array}{l}100 \% \text { no } \\
\text { sediment }\end{array}$ & $\begin{array}{l}0 \% \text { yes sedi- } \\
\text { ment }\end{array}$ & $100 \%$ no & $0 \%$ yes & $100 \%$ no & $0 \%$ yes & $100 \%$ no & $0 \%$ yes \\
\hline
\end{tabular}

Clot-On-Boiling Tests (COB) and Alcohol Perception Test (APT)

Table 4: Values for clot-on-boiling and alcohol test of different milk samples.

\begin{tabular}{|c|c|c|c|c|}
\hline \multirow{2}{*}{ Sources } & \multicolumn{2}{|c|}{$\begin{array}{c}\text { clot-on-boiling test } \\
\text { results }\end{array}$} & \multicolumn{2}{|c|}{ alcohol test results } \\
\cline { 2 - 5 } & $\begin{array}{c}\text { Accepts } \\
\text { (\%) }\end{array}$ & $\begin{array}{c}\text { Rejects } \\
\text { (\%) }\end{array}$ & $\begin{array}{c}\text { Accepts } \\
(\%)\end{array}$ & $\begin{array}{c}\text { Rejects } \\
\text { (\%) }\end{array}$ \\
\hline Milk Producer (S1) & 90 & 10 & 80 & 20 \\
\hline Cafeteria (S2) & 80 & 20 & 70 & 30 \\
\hline Control (S3) & 100 & 0 & 100 & 0 \\
\hline $\begin{array}{c}\text { Control + 5\% } \\
\text { water(S4) }\end{array}$ & 100 & 0 & 100 & 0 \\
\hline
\end{tabular}

The results pertaining to the clot on boiling test and alcohol test are presented in Table 4 . Results revealed that $20 \%$ of milk samples from cafeterias and $10 \%$ of milk from milk producers failed to match in clot on boiling test respectively. The difference in $\mathrm{COB}$ values for milk producers (S1) and cafeterias (S2) might be due to the management practices during the handling of raw milk. Differences in COB values are the main reasons of quality deterioration of milk. [29] revealed that deterioration increases as the steps increase towards marketing.

The result of the alcohol test among all three sources of milk shows high reject cases recorded in cafeteria (S2) 30\% and 20\% Milk Producer (S1) values. The result shows high level of acid concentration in the milk samples that indicate low quality milk. Milk coagulated only when the acidity of milk reached 0.21 - 
$0.23 \%$. According to the results the percentage of rejection was slightly lower in milk producer (S1) as compared to milk sample from cafeteria (S2). The problems may be due to long time storage of milk. The present results are in line with [28], who observed similar results in milk samples taken from market.

Table 5 shows correlation coefficients among the different milk quality parameters. Density of raw milk was negatively correlated with fat content and positively correlated with solid non-fat. Protein content was positively correlated with fat content. In addition, protein was correlated positively with both SNF and density whereas lactose was correlated positively with SNF, density and protein. On the other hand, adulterations (water addition) were negatively correlated with Fat, SNF, density, Total solid, protein and lactose.

Table 5: Correlation coefficients strength among different milk quality parameters in the study areas.

\begin{tabular}{|c|c|c|c|c|c|c|c|}
\hline $\begin{array}{l}\text { Vari- } \\
\text { able }\end{array}$ & Fat & $\begin{array}{l}\text { Den- } \\
\text { sity }\end{array}$ & $\begin{array}{l}\text { Lac- } \\
\text { tose }\end{array}$ & $\begin{array}{l}\text { Total } \\
\text { solid }\end{array}$ & Protein & SNF & $\begin{array}{c}\text { Water } \\
\text { add }\end{array}$ \\
\hline \multirow{2}{*}{ Fat } & \multirow{2}{*}{1} & -0.15 & -0.179 & 0.195 & 0.178 & -0.369 & -0.612 \\
\hline & & 0.678 & 0.619 & 0.587 & 0.621 & 0.292 & 0.059 \\
\hline \multirow{2}{*}{ Density } & & \multirow{2}{*}{1} & 0.275 & 0.212 & 0.186 & 0.285 & -0.507 \\
\hline & & & 0.44 & 0.555 & 0.605 & 0.424 & 0.134 \\
\hline \multirow{2}{*}{ Lactose } & & & \multirow{2}{*}{1} & 0.698 & 0.685 & 0.761 & -0.4 \\
\hline & & & & 0.024 & 0.028 & 0.01 & 0.251 \\
\hline \multirow{2}{*}{$\begin{array}{l}\text { Total } \\
\text { solid }\end{array}$} & & & & \multirow{2}{*}{1} & 0.997 & 0.838 & -0.675 \\
\hline & & & & & 0.0001 & 0.002 & 0.032 \\
\hline \multirow{2}{*}{ Protein } & & & & & \multirow{2}{*}{1} & 0.846 & -0.646 \\
\hline & & & & & & 0.002 & 0.043 \\
\hline \multirow{2}{*}{ SNF } & & & & & & \multirow{2}{*}{1} & -0.299 \\
\hline & & & & & & & 0.4 \\
\hline $\begin{array}{c}\text { Water } \\
\text { add }\end{array}$ & & & & & & & 1 \\
\hline
\end{tabular}

\section{Conclusion and Recommendation}

The results of the physical examination, chemical composition and milk adulteration clearly showed that the milk sold at Hossana city was to some extent put to the mismanagements such as adulteration of milk with water which was carried out during the handling of milk starting from milking till the receiving by end consumer to overcome the gap between demand and supply. Probably everyone involved in the milk marketing chain diluted milk to some extent directly or indirectly but very intentionally. Clot-on-boiling tests (COB) and alcohol perception test (APT) showed that milk sample from house hold milk has superior quality to cafeterias milk. Organoleptic test result regarding taste and color is also better in-house hold milk sample. In case of flavor, house hold milk and control have quite better results than the cafeteria milk. In general, it is not fair to conclude that some of the milk quality parameter sold at Hossana city, met the minimum legal standards of normal milk. Therefore, it is recommended that introducing different dairy technologies should be supported with a continuous training on how to manage a dairy farm. Stronger milk quality control and quality base payment could help a lot to discourage adulteration.

\section{Acknowledgement}

The authors gratefully acknowledge Wachemo University for financial support and shola dairy enterprise staffs for supporting with laboratory facilities for the study. Finally, great appreciation goes to the community and milk sellers who contributed to this study.

\section{References}

1. CSA (Central Statistical Agency) (2008) Agricultural sample survey. Report on livestock and livestock characteristics. (private peasant holdings), Addis Ababa, Ethiopia.

2. CSA (Central Statistical Agency) (2013) Agricultural sample survey. Report on livestock and livestock characteristics. The Federal Democratic republic of Ethiopia, Private Peasant Holdings, Ethiopia.

3. CSA (Central Statistical Agency) (2014) Agricultural sample survey. Report on livestock and livestock characteristics. The Federal Democratic republic of Ethiopia. Private Peasant Holdings, Ethiopia.

4. MoARD (Ministry of Agriculture and Rural Development) (2007) Livestock Master Plan Study, Phase I Report: Sociological Aspects. Addis Ababa, Ethiopia.

5. Javaid SB, Gadahi JA, Khaskeli M, Bhutto MB, Kumbher S, et al. (2009) Physical and chemical quality of market milk sold at tandojam. Pak J 29: 1.

6. Olatunji EA, Jubril AE, Okpu EO, Olafadehan OA, Ijah UJ, et al. (2012) Bacterial Assessment and Quality Analysis of Raw Milk Sold in Gwagwalada Area Council of the Federal Capital Territory (FCT) Abuja, Nigeria. Food Science and Quality Manage pp. 6088

7. Faraz LAM, Mustafa MI, Akhtar P, Yaqoob M, Rehman S (2013) Detection of adulteration. chemical composition and hygienic Status of milk supplied to various canteens of educational Institutes, Ethiopia.

8. Ramesh C Chandan (2006) Manufacturing Yogurt and Fermented Milks. (6 $6^{\text {th }}$ edn), Blackwell Publishing Ltd, Oxford, UK, p. 7-40.

9. Khan MTG, Zinnah MA, Siddique MP, Rashid MHA, Islam, et al. (2008) Physical and Microbial Qualities of Raw Milk Collected from Bangladesh Agricultural University Dairy Farm and the Surrounding Villages. Bangladesh Agricultural University, Bangladesh, Bangl J Vet Med 6: 217-221.

10. El-Loly MM, Mansour AIA, Ramadan OARO (2013) Evaluation of Raw Milk for Common Commercial Additives and Heat Treatments. Int J Food Safety 15: 7-10.

11. Marth EH (1978) Standard Methods for the Examinations of Dairy Products. American Public Health Association, Washington, DC, USA, 68: 173-186.

12. Khan BB, Yaqoob M, Riaz M, Younas M, Iqbal M (2005) Livestock Management Manual. Deptt. Livestock Management, Univ Agri Faisalabad Pakistan.

13. Marshall RT (1992) Standard methods for the examination of dairy products $\left(16^{\text {th }}\right.$ edn), Washington, DC, USA.

14. AOAC (2000) Official Methods of Analysis. Association of Official Analytical Chemists. $\left(17^{\text {th }}\right.$ edn), Washington, DC, USA.

15. Dehinenet G, Mekonnen H, Ashenafi M, Emmanuelle G (2013) Determinants of raw milk quality under a smallholder production system in selected areas of Amhara and Oromia National Regional States, Ethiopia. Agric Biol J N Am 4(1): 84-90. 
16. Francesconi GN (2006) Promoting Milk Quality of Cooperative Smallholders: Evidence from Ethiopia and Implications for Policy. In: Proceedings of Institutional Arrangements and Challenges in MarketOriented Livestock Agriculture in Ethiopia, 14th Annual Conference of the Ethiopian Society of Animal Production (ESAP) Held in Addis Ababa, Ethiopia, p. 32-39.

17. Derese $T$ (2008) Present situation of urban and peri-urban milk production and quality of raw milk produced in west Shoa zone, Oromia Region, Ethiopia. Thesis Haramaya University, Ethiopia.

18. Aysheshim B, Fekadu B, Mitiku E (2015) Chemical composition and microbial quality of cow milk in urban and peri urban area of Dangila town, Western Amhara Region, Ethiopia. Glob J Dairy Farm Milk Prod 3(1): 081-085.

19. Fikrineh N, Estefanos T, Tatek W (2012) Microbial Quality and Chemical Composition of Raw Milk in the Mid-Rift Valley of Ethiopia. African Journal of Agricultural Research 7: 4167-4170.

20. Ethiopian Standard (2009) Unprocessed Whole/Raw Cow Milk Specification. ( $\left.2^{\text {nd }} e d n\right)$, pp. 3460.

21. Raff H (2011) Market implications of changing fat content of milk and dairy products, fat content and composition of animal products. J Food Sci Technol 5(2): 6-17.

22. Cervalhao MP, Carbalho MP, Duraes MC, Martins CE, Deresz F, et al. (2000) Effect of nutrition on milk quality and composition. Anais do

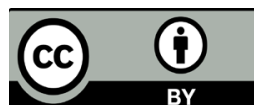

This work is licensed under Creative Commons Attribution 4.0 License DOI: 10.19080/JDVS.2018.06.555699 2o Minas Leite. Avanc tecnologicos para o aumento da produtividade leiteira, Juiz de Fora, MG, Brazil, May 2000. Anais do 2o Minas Leite. Avancos tecnologicos para oaumento da produtividade leiteira pp. 7782.

23. Asaminew Tassew (2007) Production, handling, traditional processing practices and quality of milk in Bahir Dar milk shed Area, Ethiopia. M Sc. Thesis, Alemaya University, Ethiopia.

24. FAO (Food and Agriculture Organization of the United Nations) (2007) Overview of the Turkish Dairy Sector within the Framework of EuAccession, Rome, Italy, p. 58.

25. Teklemichael T (2012) Quality and Safety of Raw and Pasteurized Cow Milk Produced and Marketed in Dire Dawa Town, M.Sc.Thesis. Haramaya University, Ethiopia.

26. Tamime AY (2009) Milk Processing and Quality Management. Society of Dairy Technology, United Kingdom.

27. Ballou LU, Pasquini M, Bremrl RD (1995) Factors affecting herd milk composition and milk plasma at four levels of somatic cell counts. Journal of Dairy Science 78(10): 2186-2195.

28. O’Mahony F (1998) Rural Dairy Technology- Experiences in Ethiopia ILCA manual No 4. Dairy Technology Unit. ILCA, Addis Abeba, Ethiopia, p. 64 .

29. Grimaud P, Serunjogi ML, Grillet N (2004) An evaluation of milk quality in Uganda. Afr J Food Agric Nutr Dev 7: 1-16.

\section{Your next submission with Juniper Publishers will reach you the below assets}

- Quality Editorial service

- Swift Peer Review

- Reprints availability

- E-prints Service

- Manuscript Podcast for convenient understanding

- Global attainment for your research

- Manuscript accessibility in different formats

( Pdf, E-pub, Full Text, Audio)

- Unceasing customer service

Track the below URL for one-step submission https://juniperpublishers.com/online-submission.php 